\title{
The problem of 'chronic mastitis' with epitheliosis
}

\author{
J. B. MACGILLIVRAY ${ }^{1}$
}

From the Department of Morbid Anatomy, Westminster Hospital Medical School, London

SYNOPSIS The incidence of breast cancer complicating chronic mastitis with epitheliosis has beenw reported to be as high as $45 \%$ and as low as $6 \%$. At least part of this discrepancy appears to be due to difficulty in distinguishing between benign and malignant intraduct epithelial proliferation.

A small series is presented here in which the incidence of invasive cancer after local excision of breast tissue showing chronic mastitis with epitheliosis was nil.

It is concluded that it is necessary to follow up larger series of cases longer before it can be saiß̋ that severe epitheliosis and borderline lesions should in all cases be treated by anything more radica\$ than local excision.

Lesions of breast tissue involving intraduct epithelial proliferation provide histopathologists with some of their most difficult problems. The borderline between proliferation of epithelium and intraduct carcinoma is ill defined and individual pathologists may vary in their assessment of any given case. Nevertheless they will be called upon to advise surgeons on the probable natural history of lesions falling into this group, and as the assessment of the risk of cancer is involved the clinicopathological responsibility is considerable.

A large literature has accumulated relating to the association between the condition variously known as chronic cystic mastitis (Foote and Stewart, 1945), fibroadenomatosis (Kiaer, 1954), cystic disease, and cystic hyperplasia (Bonser, Dossett, and Jull, 1961) with breast cancer. These authors and many others agree that the condition which is referred to in this paper as 'chronic mastitis' is associated with an increased liability to breast cancer, particularly when there is intraduct epithelial proliferation.

Davis, Simons, and Davis (1964), after reviewing the world literature, estimated the incidence of breast cancer in all women with chronic mastitis as 2.64 times that of women in general. Authorities differ considerably as to the incidence of cancer when intraduct epithelial proliferation is a feature of chronic mastitis. Davis et al (1964) found that only one out of 16 of their cases $(6 \cdot 25 \%)$, showing what they describe as 'solid epithelial hyperplasia' in an excision biopsy, subsequently developed breast cancer. But in the series of Kiaer (1954), who divided

Received for publication 22 August 1968.

'Present address: Department of Pathology, Maryfield Hospital, Dundee. his 321 cases of fibroadenomatosis into three grades according to the extent of the epithelial proliferation, no less than nine out of 20 women $(45 \%)$ with gradg 3 fibroadenomatosis developed breast cancer.

Such marked variation in the recorded incidencE of carcinoma complicating chronic mastitis wit/ intraduct epithelial proliferation underlines th』 pathologist's difficulty in advising the surgeon and justifies further study.

\section{TERMINOLOGY}

From descriptions of the pathology of chronie mastitis (Foote and Stewart, 1945; Kiaer, 1954? Bonser et al, 1961) it is apparent that variations is terminology can lead to confusion. 'Epitheliosis' is used here to describe intraduct epithelial proliferation (Figs. 1, 2, 3 and 4) and it must be clearly distinguisheव from 'adenosis', which is a proliferation an $\$$ branching of the lobular tree (Fig. 5) and is not regarded as being precancerous (Dawson, 1933)? Epitheliosis may be accompanied by a variable amount of fibrovascular proliferation (Fig. 6), and where the latter predominates the appearances merge into papillomatosis of the duct characterize by broad fibrovascular papillae covered by a single or double layer of epithelium (Fig. 7).

It is important to distinguish epitheliosis from intraduct carcinoma. Carcinoma of the breast arise $\bar{S}$ from the epithelium of the ducts or less frequentl| from the lobules. So long as the tumour is confine to the lumina of the ducts or their terminal parts within the lobules the terms 'intraduct carcinoma? (Muir, 1941) and 'lobular carcinoma in situ' (Foot8 
and Stewart, 1941) are used. Gowing (1968) recognizes three patterns of intraduct carcinoma - solid, cribıform, and papillary. A well known form of the solid intraduct carcinoma is the comedocarcinoma which is characterized by marked cellular atypia and necrosis (Fig. 9).

\section{MATERIAL}

Between 1946 and 1963, out of a series of over 1,000 cases of chronic mastitis referred to Westminster Hospital, 60 excision biopsies were reported as showing epitheliosis. During the same period 20 cases were diagnosed as intraduct carcinoma. Follow-up information, largely from the patients' own doctors, was obtained in 29 of the first group, and from the second group such information was available in 15, who were followed up as outpatients. The sections from these 44 cases were reviewed.

\section{GRADING EPITHELIOSIS}

A rough quantitative method of grading epitheliosis

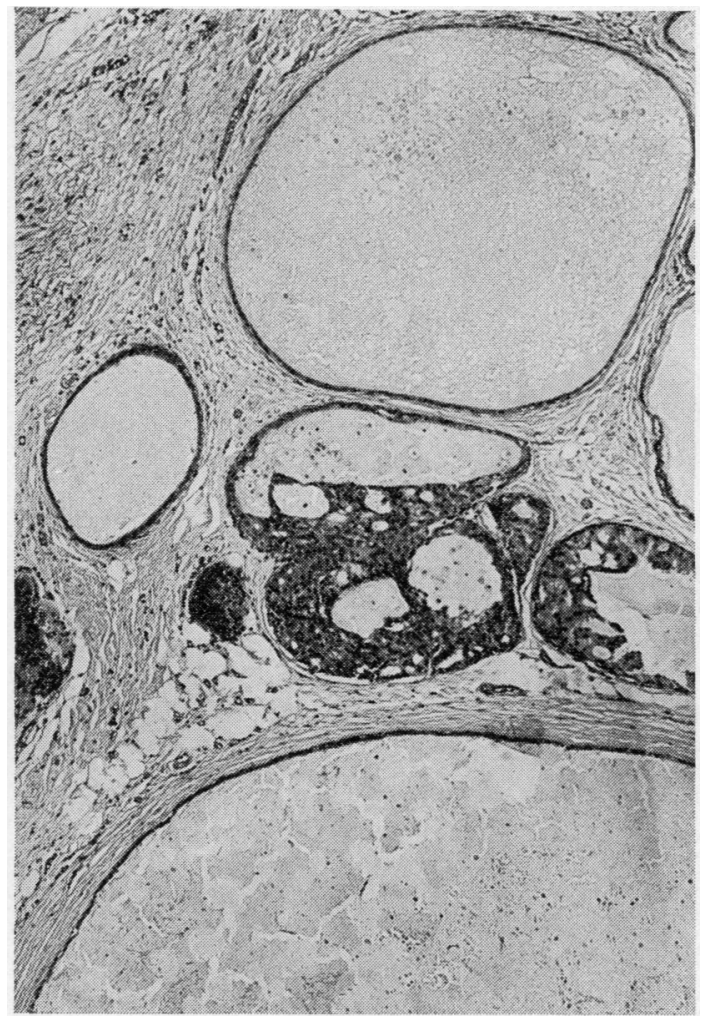

FIG. 1 according to the number of ducts affected was adopted. The limitations of the technique are obvious, and it should be emphasized that cases showing cellular atypia were not classified as epitheliosis. The intraduct epithelial changes were finally graded as follows:

SLIGHT EPITHELIOSIS This is defined as epithelial proliferation partly or completely filling less than three or four ducts in any low-power field (Fig. 1).

SEVERE EPITHELIOSIS Epithelial proliferation which completely fills more than three or four ducts in any low-power field (Figs. 2, 3 and 4).

BORDERLINE MALIGNANCY Epithelial proliferation with some cellular atypia or other features where a definite diagnosis of intraduct carcinoma could not be made (Figs. 8a and $b$ ).

INTRADUCT CARCINOMA A definite diagnosis of intraduct carcinoma was only made if there was

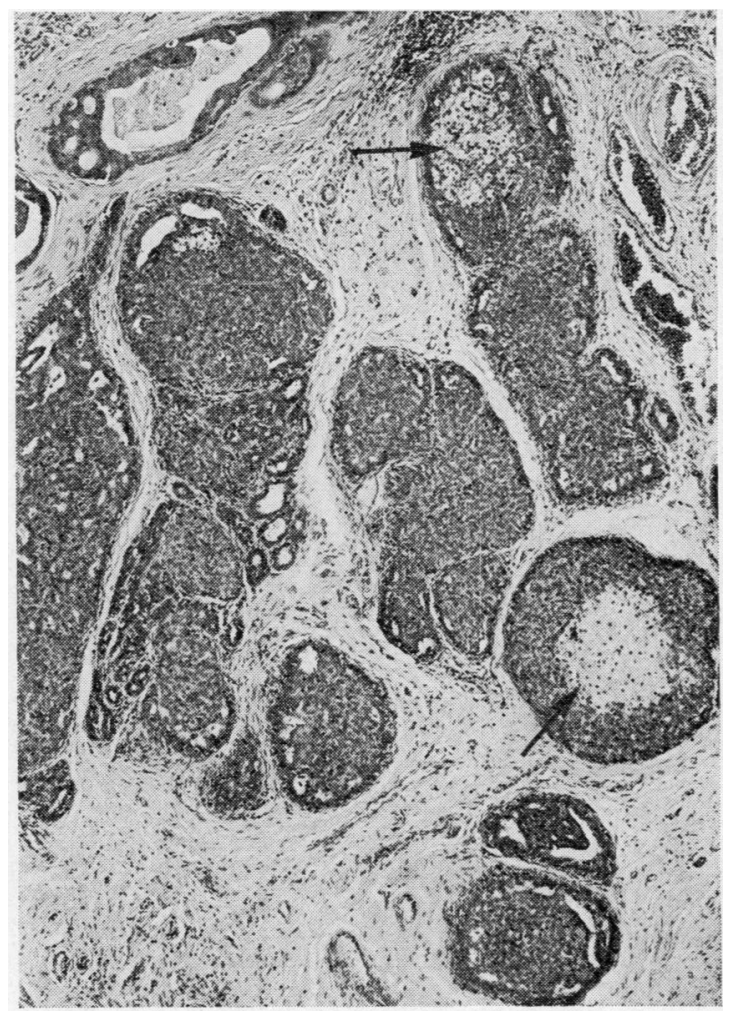

FIG. 2

FIG. 1. Slight epitheliosis. Three ducts are partly filled by proliferated epithelium. Haematoxylin and eosin $\times 36$. FIG. 2. Severe epitheliosis. Numerous ducts are completely filled by epithelium. Note the presence of foamy cells amongst the epithelium in some of the ducts (arrows). Haematoxylin and eosin $\times 36$. 


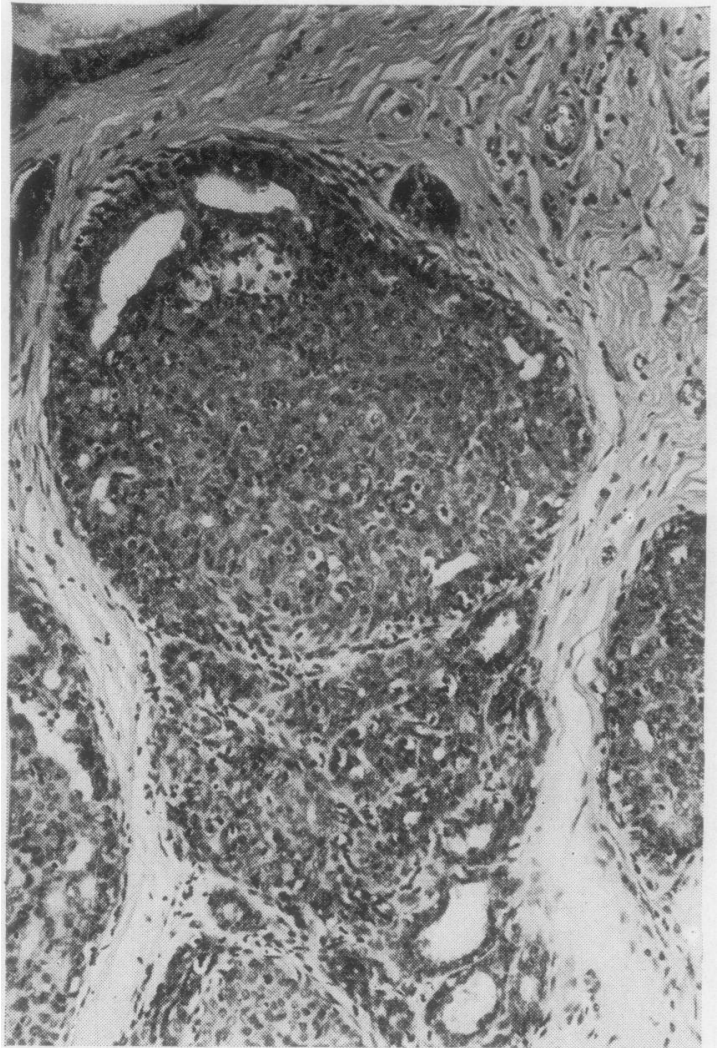

FIG. 3

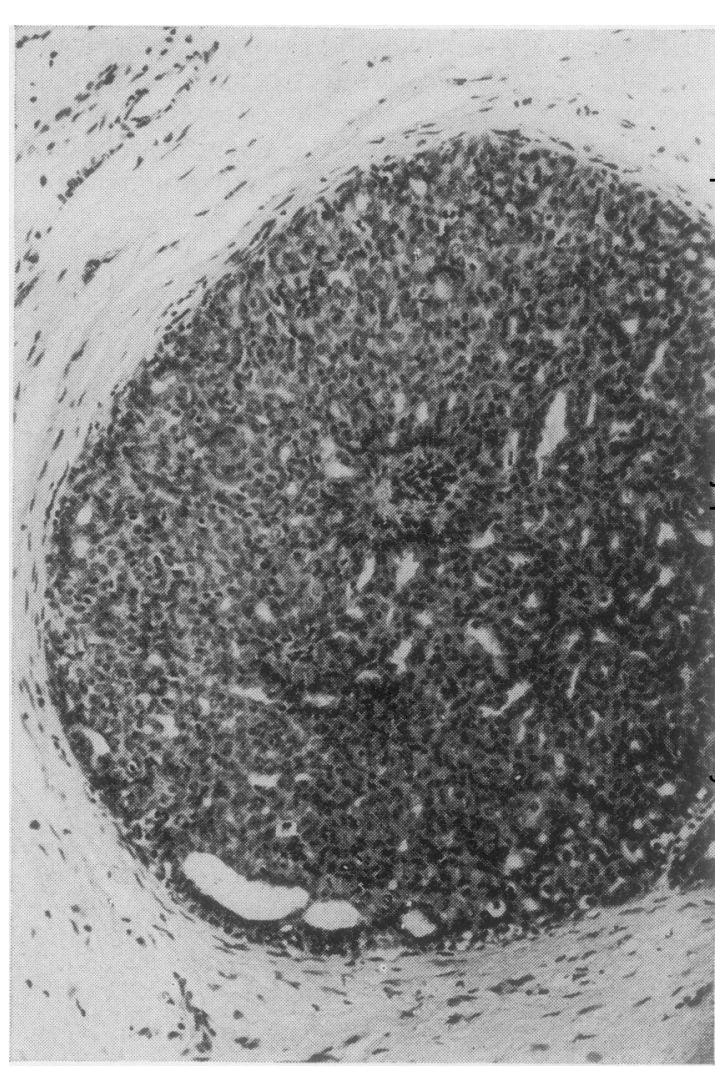

FIG. 4

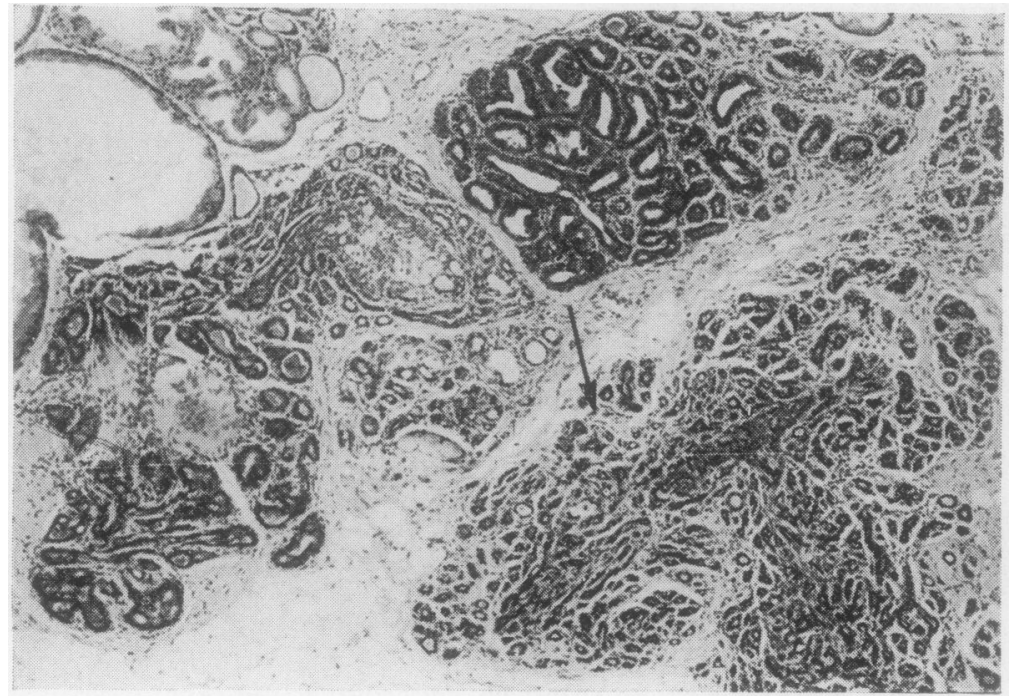

FIG. 5
FIG. 3. High-power view of one of the ducts in Fig. 2 showing variation in shape and intensity of staining of the nuclei of the cells filling the duct. Haematoxylin and eosin $\times 90$.

FIG. 4. Duct from another field in the same section as shown in Figures 2 and 3. There is variation in shape and intensity of staining of the nuclei as in Fig. 3, but there is also an acinar pattern and some fibrovascular proliferation. Haematoxylin and eosin $\times 90$.

FIG. 5. Adenosis showing proliferation and branching of the lobular tree. In the area marked with the arrow, the appearances are becoming those of sclerosing adenosis. Haematoxylin and eosin $\times 36$. 


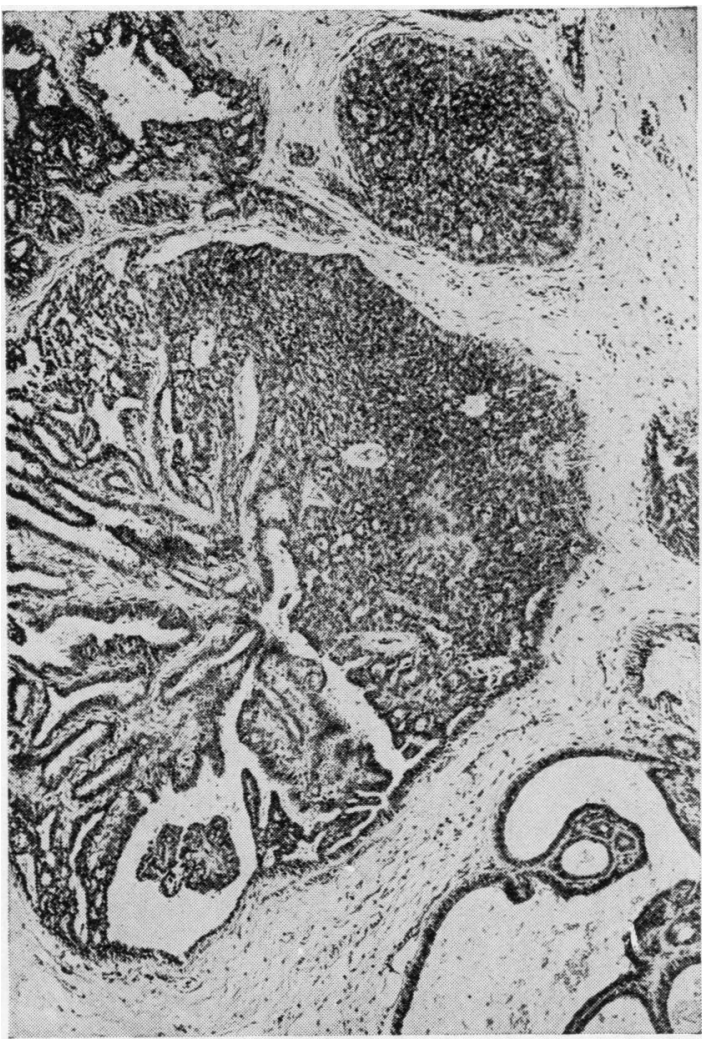

FIG. 6

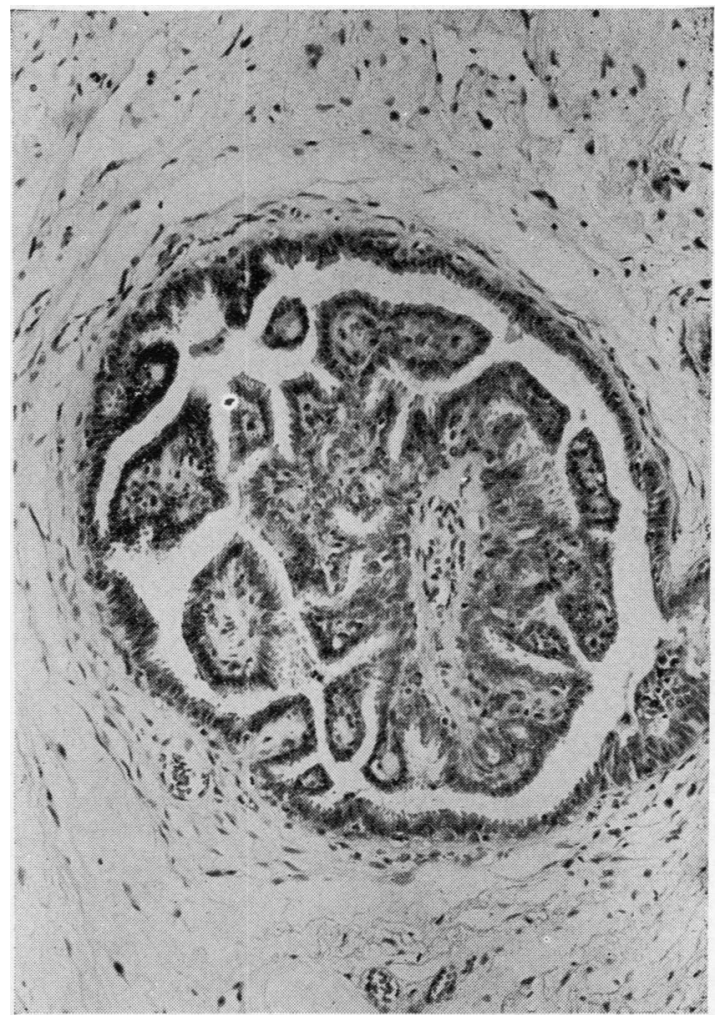

FIG. 7

FIG. 6. On one side of a dilated duct epithelial proliferation predominates, while towards the other the amount of fibrovascular tissue increases and the appearances merge into those of duct papillomatosis. Haematoxyiin and eosin $\times 45$. FIG. 7. Duct papillomatosis. Fibrovascular papillae covered by a single layer of epithelium. Haematoxylin and eosin $\times 90$.

marked cellular atypia often accompanied by appreciable mitotic activity and necrosis (Fig. 9).

\section{RESULTS}

My own review of the sections resulted in two of the cases originally diagnosed as epitheliosis being transferred to the malignant or borderline group, and five of those of the presumed intraduct carcinoma being reclassified as epitheliosis (Tables I and II). This fact underlines the variation in personal interpretation of these intraduct lesions which obviously has an important influence on treatment (Table I, cases 1 to 5).

Of the 30 patients with epitheliosis treated by local excision (including three originally diagnosed as intraduct carcinoma) none have returned with breast cancer, and all were alive and well when last heard of (Table I). This includes 10 patients with severe epitheliosis, eight of whom were followed up for over five years.

Table II shows that the patients with intraduct carcinoma and those on the borderline have done well, no deaths from breast cancer occurring in the group. All but three (Table II, cases 1, 2, and 6) had a simple or radical mastectomy. In case 7 mastectomy performed six years after intraduct carcinoma was found in an excision biopsy revealed invasive carcinoma.

\section{DISCUSSION}

Any study of a small number of cases must be of limited value, but the findings in the present series suggest that the short-term risk of cancer complicating all cases of chronic mastitis with epitheliosis is small. But how can the remarkable variation in the recorded incidence of carcinoma complicating 


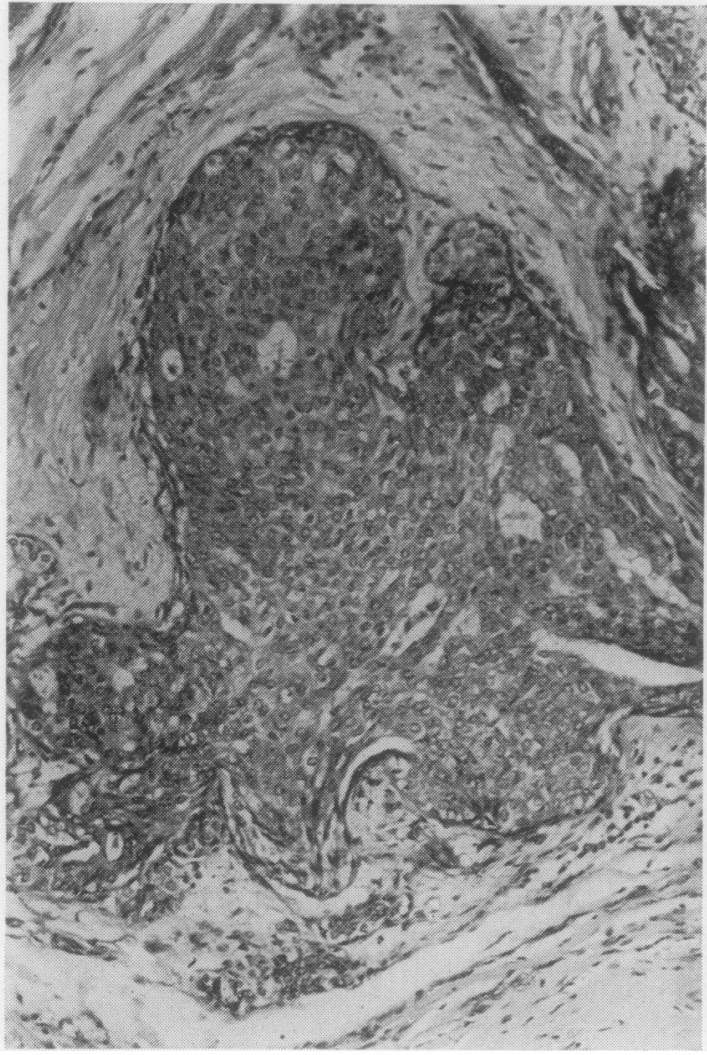

FIG. 8a

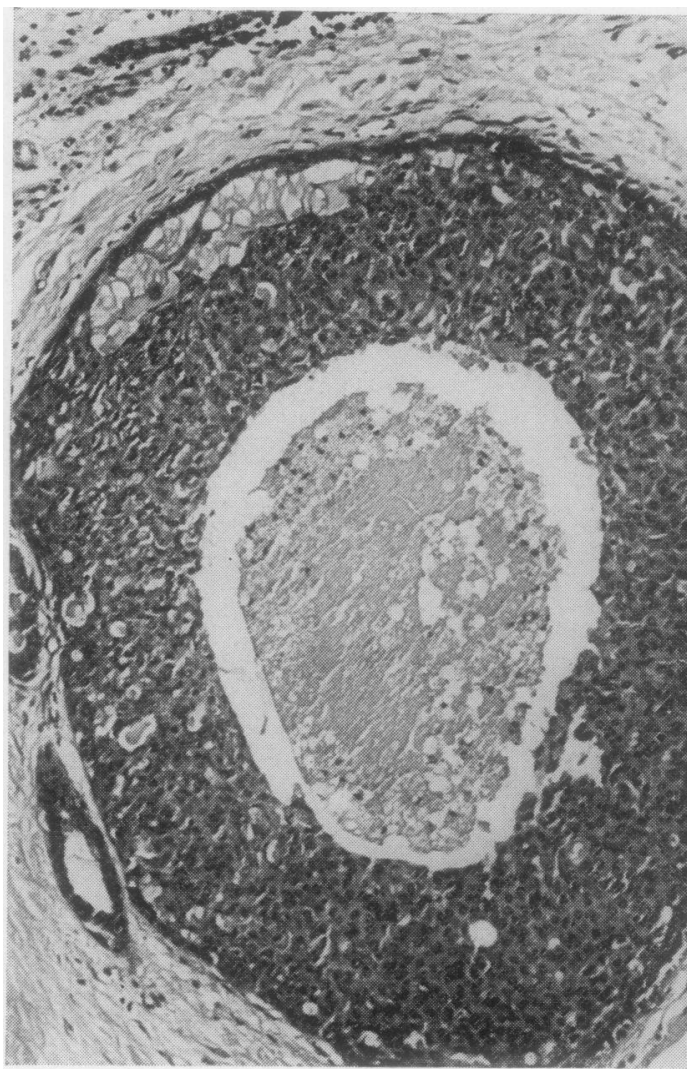

FIG. $8 \mathrm{~b}$

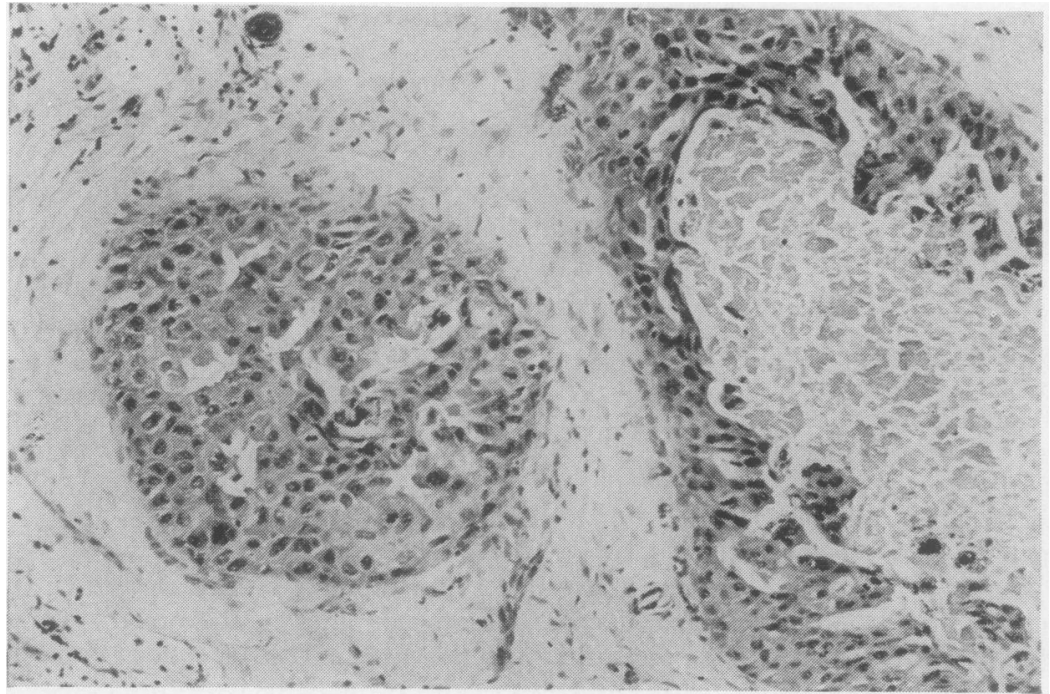

FIG. 8a. Classed as a borderline lesion due to resemblance to the variety of intraduct carcinoma characterized by pale staining cells arranged with their long axes at right angles to the walls of the ducts.

Haematoxylin and eosin $\times 90$. 윽

FIG. 8b. The presence of central necrosis resulted in classing as a borderline lesion. O Haematoxylin and eosin $\times 90$. N

FIG. 9. Comedocarcinoma showing necrosis, marked cellular pleiomorphism, and mitotic activity. Haematoxylin and eosin $\times 90$.

FIG. 9 


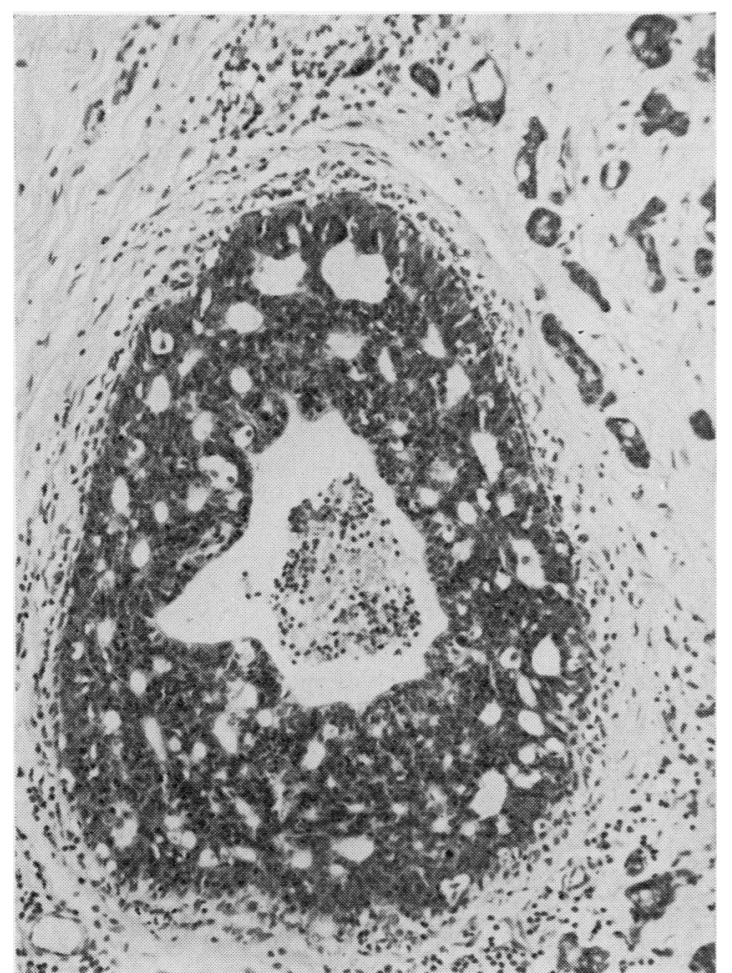

FIG. 10

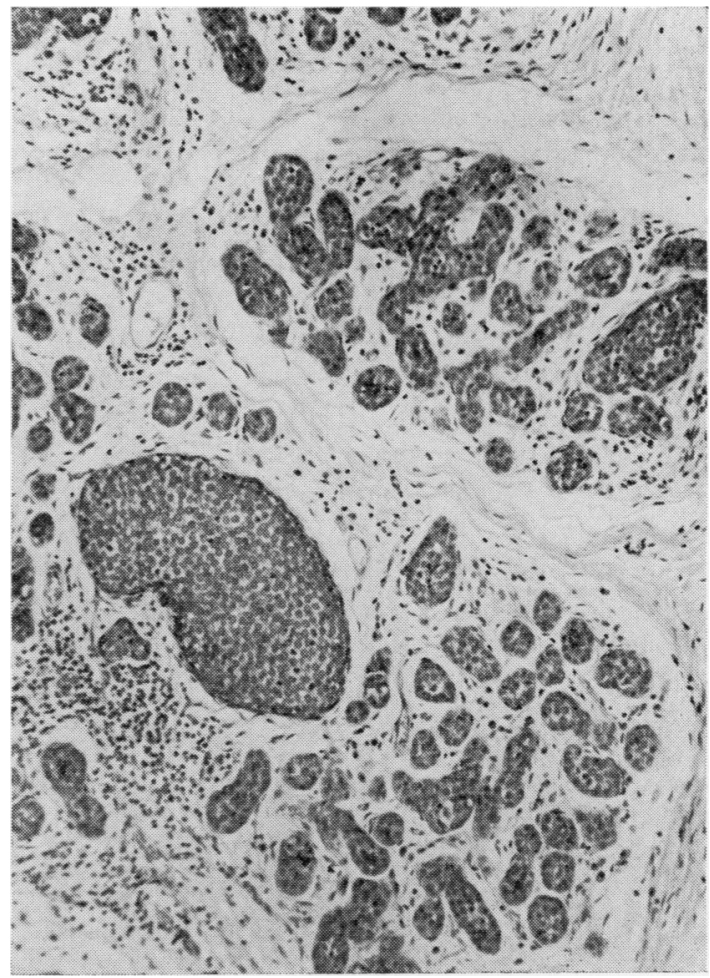

FIG. 11

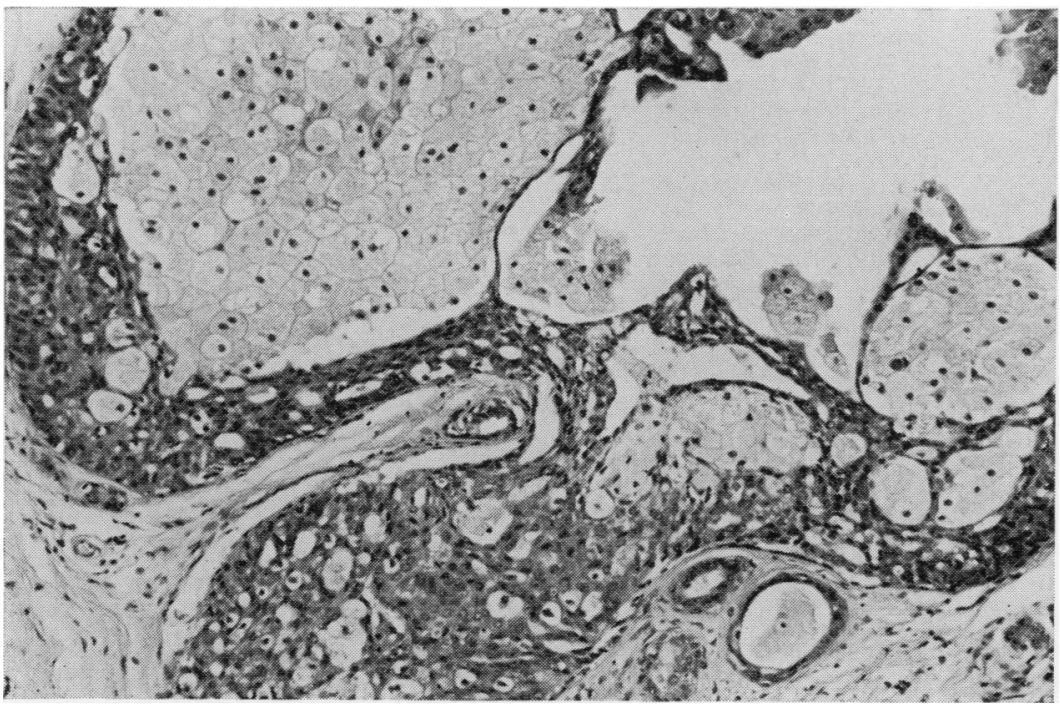

FIG. 12
FIG. 10. In this cribiform intraduct carcinoma the cytological features of malignancy are less obvious than in Figure 9. The malignant nature of the process is, however, shown by the invasive carcinoma in the surrounding breast tissue. Haematoxylin and eosin $\times 90$.

FIG. 11. Lobular carcinoma in situ. Ductules filled with uniform cells showing occasional mitotic figures. Haematoxylin and eosin $\times 90$.

FIG. 12. Degeneration of epitheliosis with formation of 'colostrum-like' foamy cells (see also Figure 2). Haematoxylin and eosin $\times 120$. 
TABLE I

\begin{tabular}{|c|c|c|c|}
\hline \multirow[b]{2}{*}{ Grade of Epitheliosis } & \multicolumn{2}{|r|}{ SUMMARY OF 32 CASES OF EPITHELIOSIS 1} & \multirow[b]{2}{*}{ Follow up and Further Treatment } \\
\hline & No. of Cases & Initial Treatment & \\
\hline Slight & 20 & Local excision & $\begin{array}{l}\text { At } 5 \text { yr, four alive and well } \\
\text { At } 5-10 \text { yr, } 13 \text { alive and well } \\
\text { Further excision same breast, chronic } \\
\text { mastitis only two cases. Excision opposite } \\
\text { breast, chronic mastitis only two cases } \\
\text { Further excision same breast, slight epitheli- } \\
\text { osis one case. Simple mastectomy opposite } \\
\text { breast, chronic mastitis only one case. } \\
10-15 \text { yr, three alive and well } \\
\text { Excision opposite breast, chronic mastitis } \\
\text { only one case }\end{array}$ \\
\hline \multirow[t]{2}{*}{ Severe } & $\begin{array}{l}\text { Original diagnosis } \\
\text { chronic mastitis with } \\
\text { epitheliosis, } 7\end{array}$ & & $\begin{array}{l}\text { At } 5 \mathrm{yr} \text {, one alive and well } \\
\text { At } 5-10 \mathrm{yr} \text {, six alive and well }\end{array}$ \\
\hline & $\begin{array}{l}\text { Original diagnosis } \\
\text { intraduct carcinoma, } 5\end{array}$ & $\begin{array}{l}\text { Case 1, local excision, } \\
\text { Case 2, local excision } \\
\text { Case 3, local excision and bilateral } \\
\text { oophorectomy } \\
\text { Case 4, local excision, radiotherapy, and } \\
\text { temporary menopause } 1955 \\
\text { Case 5, radical mastectomy }\end{array}$ & $\begin{array}{l}\text { At } 2 \mathrm{yr} \text {, alive and well, pregnant } \\
\text { At } 3 \mathrm{yr} \text {, simple mastectomy showed severe } \\
\text { epitheliosis. } \\
\text { At } 8 \mathrm{yr} \text {, alive and well } \\
\text { At } 12 \mathrm{yr} \text {, alive and well, } 1960 \text { pregnancy } \\
\text { terminated and sterilized } \\
\text { At } 7 \mathrm{yr} \text {, alive and well }\end{array}$ \\
\hline
\end{tabular}

${ }^{1}$ Average follow up of all cases was seven years.

\section{TABLE II}

\section{SUMMARY OF 12 CASES OF INTRADUCT CARCINOMA OR BORDERLINE MALIGNANCY}

\begin{tabular}{|c|c|c|c|}
\hline Grading & No. of cases & Initial Treatment & Length of Follow $U p$ and Further Treatment \\
\hline Borderline & 5 & $\begin{array}{l}\text { Case } 1 \text {, local excision (original diagnosis } \\
\text { epitheliosis) } \\
\text { Case } 2 \text {, local excision and radiotherapy } \\
\text { Case } 3 \text {, simple mastectomy } \\
\text { Case } 4 \text {, radical mastectomy } \\
\text { Case 5, radical mastectomy }\end{array}$ & $\begin{array}{l}4 \mathrm{yr} \text {, alive and well } \\
10 \mathrm{yr} \text {, alive and well } \\
6 \mathrm{yr} \text {, alive and well } \\
8 \mathrm{yr} \text {, alive and well } \\
12 \mathrm{yr} \text {, died of coronary thrombosis }\end{array}$ \\
\hline Intraduct carcinoma & $\begin{array}{l}7 \text { ( } 2 \text { with Paget's disease } \\
\text { of the nipple) }\end{array}$ & $\begin{array}{l}\text { Case } 8 \text {, simple mastectomy (with Paget's } \\
\text { disease) } \\
\text { Case } 9 \text {, simple mastectomy (with Paget's } \\
\text { disease) } \\
\text { Case } 10 \text {, simple mastectomy } \\
\text { Case } 11 \text {, radical mastectomy } \\
\text { Case } 12 \text {, radical mastectomy }\end{array}$ & $\begin{array}{l}12 \text { yr, alive and well } \\
\text { Further local excision } 1958 \text {, extensive IDC. } \\
\text { Simple mastectomy } 1959 \text { revealed invasive } \\
\text { carcinoma. Alive and well } 14 \text { years after } \\
\text { original biopsy } \\
5 \text { yr, alive and well }\end{array}$ \\
\hline
\end{tabular}

chronic mastitis with epitheliosis be explained?

The paper of Davis et al (1964) contains few illustrations, and it is thus difficult to compare their results with those of Kiaer (1954) and my own results. Kiaer's monograph, on the other hand, is extensively illustrated, and if one assumes that what I have called 'severe epitheliosis' is similar to the grade 3 fibroadenomatosis of Kiaer, in whose series nine out of 20 cases developed breast cancer, there is an obvious discrepancy, even after allowing for the smaller number of cases in my series.

There are two possible explanations. The length of follow up is clearly important. Of Kiaer's 321 cases of fibroadenomatosis of all grades the average follow up was 17 years compared with seven years in the $N$ present series. Two of Kiaer's cases of grade 3 N fibroadenomatosis did not develop breast cancer until 18 and 24 years after local excision. I agree with

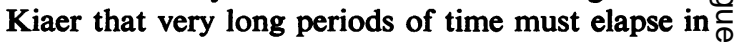
assessing the malignant potential of epitheliosis.

The average follow up period of the 16 cases of 0 Davis et al (1964) showing 'solid epithelial hyper- ${ }^{\circ}$ plasia', of which only one developed breast cancer, $\stackrel{\mathbb{D}}{\circ}$ was 14 years, which is comparable to that in Kiaer's $\mathbb{D}$ series. This suggests that another possible factor in $\frac{\circ}{\sigma}$ the high incidence of malignancy in Kiaer's series is 
the inclusion of cases which some pathologists, including myself, might have labelled intraduct carcinoma or lobular carcinoma in situ.

Comedocarcinoma is easily recognized (Fig. 9) but in certain other forms of intraduct carcinoma (Fig. 10) and lobular carcinoma in situ (Fig. 11), the cells filling the ducts may be remarkably uniform and mitotic figures scanty. In the absence of invasion of the surrounding tissues the malignant nature of the epithelium may not be recognized, especially when the number of ducts affected is small. In case 7 (Table II) of the present series carcinoma was confined to the ducts for at least seven years, and in the case described by Godwin (1952) there was a latent period of 12 years before lobular carcinoma in situ became invasive. Clearly the incidence of invasive carcinoma in any series will be increased if cases with malignant intraduct lesions are included.

It is my own experience, however, that it is more common for lesions which are not actually malignant to be diagnosed as intraduct carcinoma (Table I). In epitheliosis the proliferation is believed to involve both the epithelium lining the ducts and the myoepithelium which lies just within the basement membrane (Kuzma, 1943; Biggs, 1947). The presence of these two types of cell within the ducts may give an impression of cellular pleiomorphism and malignancy.

Muir (1941) and Dawson (1948) both agree that a sequence can be traced from epitheliosis to intraduct carcinoma, and that it is impossible to state when malignancy actually occurs. Epitheliosis is not inevitably progressive, and Dawson (1948) holds the view that many of the cysts seen in chronic mastitis are due to the degeneration of epitheliosis with the formation of 'colostrum-like' foam cells which subsequently disintegrate (Fig. 12). Muir (1941) also pointed out that the number of cases in which the progression of epitheliosis to intraduct carcinoma could be traced was small, and suggested that often there was a more direct development of malignancy from duct epithelium without a preceding phase of epithelial hyperplasia.

Although the results of surgery are excellent when breast cancer is confined to the ducts (Gillis,
Dockerty, and Clagett, 1960), the case for performing mastectomy for epitheliosis seems as yet unproven. My own views are in accord with those of Foote and Stewart who as long ago as 1945 stated that the rationale of simple mastectomy in "chronic cystic mastitis", so far as we can ascertain, has not yet been clearly demonstrated. The performance of this operation for "chronic cystic mastitis" should be discarded until specific lesions are proved beyond doubt to be followed by cancer in a sufficiently high percentage of cases to warrant this procedure.'

Information regarding the long-term potential of epitheliosis to become malignant will only be obtained by following up a large number of women treated by local excision only for a very long time. Until then borderline cases and those showing severe epitheliosis present a clinicopathological problem which must be shared by surgeon and pathologist. Management of individual cases may have to take into account other factors, such as the extent of the disease in both breasts and the effect of a mutilating operation, possibly on a young woman.

I wish to thank the surgeons of the Westminster and Gordon Hospitals who allowed me to study their cases, and the Department of Medical Photography, Westminster Medical School, for the photomicrographs. My special thanks are due to Professor A. D. Morgan and Dr D. H. MacKenzie for their advice and encouragement.

\section{REFERENCES}

Biggs, R. (1947). J. Path. Bact., 59, 437.

Bonser, G. M., Dossett, J. A., and Jull, J. W. (1961). Cystic disease and epithelial proliferation as pre cancerous conditions in the human breast. In Human and Experimental Breast Cancer, p. 316. Pitman, London.

Davis, H. H., Simons, M., Davis, J. B. (1964). Cancer (Philad.), 17, 957.

Dawson, E. K. (1933). Edinb. med. J., 40, 57.

(1948). Ann, roy. Coll. Surg. Engl., $2,241$.

Foote, F. W. Jr., and Stewart, F. W. (1941). Amer. J. Path., 17, 491. - - (1945). Ann. Surg., 121, 197.

Gillis, D. A., Dockerty, M. B., and Clagett, O. T. (1960). Surg. Gynec. Obstet., 110, 555

Godwin, J. T. (1952). Cancer (Philad.), 5, 259.

Gowing, N. F. C. (1968). Hosp. Med., 2, 380.

Kiaer, W. (1954). Relation of Fibroadenomatosis ('Chronic Mastitis') to Cancer of the Breast. Munksgaard, Copenhagen.

Kuzma, J. F. (1943). Amer. J. Path., 19, 473.

Muir, R. (1941). J. Path. Bact., 52, 155. 